\title{
PENGARUH NPL, LDR, GCG , NIM , ROA , ROE , CAR ,BOPO TERHADAP HARGA SAHAM PADA PERUSAHAAN PERBANKAN YANG TERDAFTAR DI BURSA EFEK INDONESIA DARI TAHUN 2010 - 2014.
}

\section{THE EFFECT OF NPL, LDR, GCG , NIM , ROA , ROE , CAR ,BOPO TOWARDS THE STOCK PRICE IN BANKING COMPANIES LISTED IN INDONESIAN STOCK EXCHANGE OF THE YEAR 2010-2014}

\author{
Dahrul Aman Harahap ${ }^{1}$, Ade Isyana Hairunnisah ${ }^{2}$ \\ ${ }^{1}$ Pendidikan Biologi, FKIP, Universitas Riau Kepulauan, Indonesia \\ ${ }^{2}$ Akuntansi, Fakultas Ekonomi, Universitas Riau Kepulauan, Indonesia \\ ${ }^{1}$ amanhrp@yahoo.com, ${ }^{2}$ nishalubis@yahoo,co.id
}

\begin{abstract}
Abstrak
Banyak faktor - faktor yang mempengaruhi harga saham, diantaranya: Gross ProfitMargin, Net Profit Margin, Return on Investment, Return on Equity, Return on Asset, Price Earning Ratio, Earning Per Shere, Debt to Equity Ratio, Current Ratio, Size Perusahaan,Growth, Deviden, Arus Kas dan sebagainya. Agar penelitian dapat lebih fokus dan mendalam,maka pada penelitian ini penelitian membatasi sesuai dengan Peraturan Bank Indonesia No:13/1/PBI/2011 2011 tanggal 5 Januari 2011 tentang Penilian Kesehatan Bank Umum yaituRisk Based Bank Rating (RBBR) melalui NPL (Non Performing Loan), LDR (Loan to Deposit Ratio), GCG (Good Corporate Governance), NIM (Net Interest Margin), ROA (Return on Assets), ROE (Return on Equity), CAR (Capital Adequacy Ratio), BOPO (Beban Operasionalterhadap Pendapatan Operasional) terhadap Harga Saham pada perusahaan Perbankan yang terdaftar di Bursa Efek Indonesia dari Tahun 2010 - 2014. Penelitian ini merupakan penelitian yang menggunakan pendekatan kuantitatif dimana data bersumber dari laporan keuangan yang dibpublikasikan oleh Perusahaan perbankkan yang terdaftar di Bursa Efek Indonesia. Terdapat 41 Perusahaan Perbankan yang terdaftar di Bursa Efek Indonesia tahun 2014, tetapi yang memenuhi kriteria sebagai sampel hanya terdapat 20 perusahaan perbankan, sedangkan angka tahun yang digunakan adalah 5 tahun berturut - turut, sehingga jumlah sampel adalah 5 × $20=100$ sampel. Untuk mengolah dan menganalisis data-data yang terkumpul dilakukan dengan distribusi frekuensi, korelasi product moment, korelasi ganda, regresi linier sederhana dan regresi ganda. Hasil dari penelitian ini adalah Non Performing Loan (X1) Terhadap Harga Saham (Y). Berdasarkan hasil perhitungan dengan SPSS table di atas tampak nilai $t_{\text {hitung }}>t_{\text {tabel }}$ yaitu $2.098>$. Yang artinya terdapat pengaruh positif dan signifikan antara Non Performing Loan (X1) Terhadap Harga Saham (Y). Loan to Deposit Ratio (X2)Terhadap Harga Saham (Y)Berdasarkan hasil perhitungan dengan SPSS table di atas tampak nilai $\mathrm{t}_{\text {hitung }}<\mathrm{t}_{\text {tabel }}$ yaitu $0.097<1955$.Yang artinya tidak terdapat pengaruh yang signifikan antara Loan to Deposit Ratio (X2)Terhadap Harga Saham (Y). Good Corporate Governance (X3) Terhadap Harga Saham (Y). Berdasarkan hasil perhitungan dengan SPSS table di atas tampak nilai $t_{\text {hitung }}>t_{\text {tabel }}$ yaitu $4.177>$. Yang artinya terdapat pengaruh positif dan signifikan antara Good Corporate Governance (X3)Terhadap Harga Saham (Y). Net Interest Margin (X4) Terhadap Harga Saham (Y). Berdasarkan hasil perhitungan dengan SPSS table di atas tampak nilai $t_{\text {hitung }}>t_{\text {tabel }}$ yaitu $2.751>1955$. Yang artinya terdapat pengaruh positif dan signifikan antara Net Interest Margin (X4)Terhadap Harga Saham (Y). Return on Assets (X5) Terhadap Harga Saham (Y). Berdasarkan hasil perhitungan dengan SPSS table di atas tampak nilai $\mathrm{t}_{\text {hitung }}<\mathrm{t}_{\text {tabel }}$ yaitu $0.672<1955$. Yang artinya tidak terdapat pengaruh yang signifikan antara Return on Assets (X5)Terhadap Harga Saham (Y). Return on Equity (X6) Terhadap Harga Saham (Y). Berdasarkan hasil perhitungan dengan SPSS table di atas tampak nilai $\mathrm{t}_{\text {hitung }}<\mathrm{t}_{\mathrm{tabel}}$ yaitu $1.951<1955$. Yang artinya tidak terdapat pengaruh yang signifikan antara Return on Equity (X6) Terhadap Harga Saham (Y). Beban Operasional / Pendapatan Operasional (X7) Terhadap Harga Saham (Y). Berdasarkan hasil perhitungan dengan SPSS table di atas tampak nilai $\mathrm{t}_{\text {hitung }}<\mathrm{t}_{\text {tabel }}$ yaitu $0.027<1955$. Yang artinya tidak terdapat pengaruh yang signifikan antara Beban Operasional / Pendapatan Operasional (X7) Terhadap Harga Saham (Y). Capital Adequacy Ratio (X8) Terhadap Harga Saham (Y). Berdasarkan hasil perhitungan dengan SPSS table di atas tampak nilai
\end{abstract}


Dahrul Aman Harahap \& Ade Isyana Hairunnisah; Pengaruh Npl, Ldr, Gcg , Nim , Roa , Roe , Car ,Bopo...

$\mathrm{t}_{\text {hitung }}>\mathrm{t}_{\text {tabel }}$ yaitu 2.923>1955. Yang artinya terdapat pengaruh positif dan signifikan antara Capital Adequacy Ratio (X8)Terhadap Harga Saham (Y). Berdasarkan hasil uji statistik Fhitung > Ftabel (20.000> 2.60). Hal ini menunjukkan bahwa variabel independen NPL, LDR, GCG, NIM, ROA, ROE, CAR dan BOPO secara simultan berpengaruh terhadap variabel dependen harga saham perusahaan perbankan yang terdaftar di BEI periode 20102014.

Kata Kunci: NPL, LDR, GCG, NIM , ROA , ROE , CAR,BOPO, Harga Saham

\begin{abstract}
There are some factors that affect stock prices, such as: Gross Profit Margin, Net Profit Margin, Return on Investment, Return on Equity, Return on Assets, Price Earning Ratio, Earnings Per Share, Debt to Equity Ratio, Current Ratio, Size Companies, Growth, Dividend, Cash Flow, and so on. In order to make the research more focused and in-depth, it was limited in accordance with Bank Indonesia Regulation No: 13/1 / PBI / 2011 2011, dated January 5, 2011 about the judging of Commercial Banks namely Risk Based Bank Rating (RBBR) through NPL (Non Performing Loan), LDR (Loan to Deposit Ratio), GCG (Good Corporate Governance), NIM (Net Interest Margin), ROA (Return on Assets), ROE (Return on Equity), CAR (Capital Adequacy Ratio), ROA (operational expense towards operating income) on stock price on the Banking companies listed on the Indonesian Stock Exchange of the Year 2010-2014. This research was a quantitative approach where the data source was from the financial statements by the Company published by banking companies listed on the Indonesia Stock Exchange. There are 41 Banking Companies listed on the Indonesia Stock Exchange in 2014, but which meet the criteria as there are only a sample of 20 banking companies, while the number of years used are five years in a row - row, so the sample size is $5 \times 20=100$ samples. To process and analyze the data collection was done with frequency distribution, product moment correlation, multiple correlation, simple linear regression and multiple regression. The results of this study are Non Performing Loan $\left(X_{1}\right)$ towards Share Price $(Y)$. Based on calculations using SPSS, tcount> ttable was 2098>. Which means that there is positive and significant correlation between the Non Performing Loan (X1) Share Price (Y). Loan to Deposit Ratio (X2) Share Price (Y). Based on calculations by using $S P S S, t_{\text {count }}<t_{\text {table }}$ was $0097<1955$.It means that there is a significant difference between the Loan to Deposit Ratio (X2) Share Price ( Y). Good Corporate Governance (X3) Share Price (Y). Based on calculations using SPSS, tcount> ttable was 4177> which means that there is positive and significant correlation between good corporate governance (X3) Share Price (Y), Net Interest Margin (X4), and Share Price (Y). Based on calculations using SPSS, tcount> ttable was 2751>1955 which means that there is positive and significant correlation between Net Interest Margin (X4) Share Price (Y). Return on Assets (X5) Share Price (Y). Based on calculations using SPSS table above looks tcount <ttable ie $0672<1955$ which means that no significant difference between the Return on Assets (X5) Share Price (Y). Return on Equity (X6) Share Price (Y). Based on calculations using SPSS , tcount <ttable was $1,951<1955$ which means that no significant difference between the Return on Equity (X6) Share Price (Y). Operating Expenses / Operating Income (X7) Share Price (Y). Based on calculations using SPSS, tcount <ttable was $0027<1955$ which means that no significant difference between Operating Expenses / Operating Income (X7) towards Share Price (Y). Capital Adequacy Ratio (X8) Share Price (Y). Based on calculations using SPSS, tcount> ttable was 2923> 1955 which means that there is positive and significant correlation between Capital Adequacy Ratio (X8) Share Price (Y). Based on the statistical test F count> F table (20,000> 2.60). It indicates that the independent variable NPL, LDR, GCG, NIM, ROA, ROE, and ROA CAR simultaneously affect the stock price of the dependent variable banking companies listed on the Stock Exchange in 2010-2014.
\end{abstract}

Key words: NPL, LDR, GCG, NIM, ROA, ROE, CAR, ROA, stock price 


\section{PENDAHULUAN}

\section{Latar Belakang Penelitian}

Perbankan merupakan pilar terpenting dalam membangun sistem perekonomian dan keuangan Indonesia karena perbankan memiliki peranan yang sangat penting sebagai intermediary institution yaitu lembaga keuangan yang menghubungkan dana yang dimiliki olehunit ekonomi yang surplus ke unit ekonomi yang membutuhkan bantuan dana (deficit). Selain itu, bank juga memiliki fungsi sebagai lembaga yang menerima dan menyalurkan kebijakan moneter yang dibuat oleh Bank Sentral. Dalam hal ini, Bank Sentral mempunyai peranan penting sebagai lembaga yang dapat menciptakan uang dan hampir seluruh proses perputaran uang dalam perekonomian terjadi melalui perbankan. karena itu bank harus bisa menjaga tingkat kesehatannya agar bisa menjalankan perannya sebagai lembaga intermediary dengan baik.

Kinerja keuangan bank dapat dinilai dari beberapa indikator, salah satu sumber utama indikator yang dijadikan dasar penilaian adalah laporan keuangan bank yang bersangkutan yaitu melalui rasio keuangan bank yang dapat dijadikan sebagai dasar penilaian tingkat kinerja bank tersebut.Indonesia dianggap sebagai negara yang tidak kompetitif untuk investasi jangka panjang. Salah satu penyebabnya adalah lemahnya penerapan praktik Good corporate Govermance(GCG) pada perusahaan di Indonesia, seperti lemahnya hukum, standar akuntansi dan pemeriksaan keuangan (auditing) yang belum mapan, pasar modal yang masih underegulated, lemahnya pengawasan komisaris, dan terabaikannya hak minoritas. Karena tujuan perusahaan adalah untuk meningkatkan nilai perusahaan secara maksimal. Dan nilai perusahaan dalam penelitian ini didefinisikan sebagai nilai pasar semakin tinggi nilai perusahaan maka akan menggambarkan semakin sejahtera pemilik perusahaan tersebut. Nilai perusahaan tersebut akan tercermin dari harga sahamnya yang beredar di pasar modal. Dan untuk memaksimumkan nilai perusahaan tidak hanya nilai ekuitas saja yang harus diperhatikan, tetapi juga semua klaim faktor keuangan seperti jumlah kewajiban, Jumlah asset dan Jumlah profitabilitasnya.

Kinerja dan kesehatan bank adalah faktor yang dilihat terlebih dahulu oleh inversor sebelum menginvestasikan dananya ke perusahaan perbankan. Perusahaan perbankan yang 
memilikikinerja dan kesehatan bank yang baik diharapan akan semakin tinggi laba usahanya dan semakin banyak keuntungan yang dapat dinikmati oleh pemegang saham, juga perusahaan tersebut akan dipercaya masyarakat karena mempunyai reputasi yang baik dan pada akhirnya dapat meningkatkan harga saham. Dan peningkatan harga saham merupakan hal yang diharapkan oleh para investor.

Oleh karena itu investor akan melihat sistem perbankan yang sehat, kuat, dan efisien sesuai dengan indicator yang ditetapkan pada Peraturan Bank Indonesia No: 13/1/PBI/2011 tentang Penilian Kesehatan Bank Umum yaitu Risk Based Bank Rating (RBBR) dengan menggunakan Risk profile (melalui Non Performing Loan dan Loan to Deposit Ratio)), GoodCorporate governance (GCG), Earnings (melalui Net Interest Margin. Return on Assets danReturn on Equit)), Capital (melalui Capital Adequacy Ratio) Efisiensi (melalui BebanOperasional terhadap Pendapatan Operasional).

Berdasarkan latar belakang di atas dapat diidentifikasi permasalahannya sebagai berikut: Bagaiman pengaruh NPL (Non Performing Loan), LDR (Loan to Deposit Ratio), GCG (GoodCorporate Governance), NIM (Net Interest Margin), ROA (Return on Assets), ROE (Return on Equity), CAR (Capital Adequacy Ratio), BOPO (Beban Operasional terhadap PendapatanOperasional) terhadap Harga Saham pada perusahaan Perbankan yang terdaftar di Bursa Efek Indonesia dari Tahun 2010 - 2014.

\section{Penjelasan Istilah}

a. Non Performing Loan (NPL) adalah tingkat pengembalian kredit yang diberikan deposan kepada bank dengan kata lain NPL merupakan tingkat kredit pada bank tersebut. Besarnya NPL yang diperbolehkan oleh Bank Indonesia saat ini adalah maksimal 5\%. NPL (Non Performing Loan) merupakan rasio yang menunjukan bahwa kemampuan manajemen bank dalam mengelola kredit bermasalah yang diberikan oleh bank

b. Loan to Deposit Ratio (LDR) untuk mengukur posisi atau kemampuan likuiditas bank. Rasio ini menyatakan seberapa jauh kemampuan bank dalam membayar kembali penarikan dana yang dilakukan deposan dengan mengandalkan kredit yang diberikansebagai sumber likuiditasnya. 
c. GCG (Good Corporate Governance) dalam perbankan telah ditetapkan oleh Bank Indonesia. Penilaian tersebut menghasilkan skor atau nilai yang dihitung berdasarkan beberapa kriteria secara self assesment (PBI No. 13/1/PBI/2011).

d. NIM (Net Interest Margin) juga disebut sebagai rentabilitas ekonomi merupakan perbandingan antara pendapatan bunga bersih dengan rata-rata aktiva produktif yang digunakan untuk menghasilkan laba tersebut (PBI No. 13/1/PBI/2011).

e. Return on Assets (ROA) digunakan untuk mengukur kemampuan manajemen dalammemperoleh keuntungan atau laba secara keseluruhan.

f. Return on Equity (ROE) merupakan suatu variabel yang muncul dari perbandingan lababersih setelah pajak dengan total equitas ini diharapkan dapat mengukur seberapa banyak keuntngan yang menjadi hak modal sendiri.

g. CAR (Capital Adequacy Ratio) merupakan rasio yang memperlihatkan seberapa jumlah aktiva bank yang mengandung risiko (kredit, penyertaan, surat berharga, yang menunjukkan kemampuan permodalan dan cadangan yang digunakan untuk menunjang kegiatan operasi perusahaan.

h. BOPO bertujuan untuk mengukur tingkat efisiensi dan kemampuan bank dalam melakukan kegiatan operasinya. Peningkatan besaran pada rasio ini mencerminkan kurangnya kemampuan bank dalam mengelola usahanya

i. Harga saham merupakan harga penutupan (closing price) dari masing-masing perusahaan perbankan selama tahun 2010-2014 dengan satuan ukuran Rupiah

\section{Hipotesis Penelitian}

Adapun hipotesis yang diajukan dalam penelitian ini adalah sebagai berikut :

1. Secara parsial tedapat pengaruh NPL (Non Performing Loan) terhadap Harga Saham perusahaan . 
Dahrul Aman Harahap \& Ade Isyana Hairunnisah; Pengaruh Npl, Ldr, Gcg , Nim , Roa , Roe , Car ,Bopo...

2. Secara parsial tedapat pengaruh LDR (Loan to Deposit Ratio) terhadap Harga Saham perusahaan

3. Secara parsial tedapat pengaruh GCG (Good Corporate Governance) terhadap Harga Saham perusahaan .

4. Secara parsial tedapat pengaruh NIM (Net Interest Margin) terhadap Harga Saham perusahaan .

5. Secara parsial tedapat pengaruh ROA (Return on Assets) terhadap Harga Saham perusahaan .

6. Secara parsial tedapat pengaruh ROE (Return on Equity) terhadap Harga Saham perusahaan .

7. Secara parsial tedapat pengaruh CAR (Capital Adequacy Ratio) terhadap Harga Saham perusahaan .

8. Secara parsial tedapat pengaruh BOPO (Beban Operasional terhadap Pendapatan Operasional) terhadap Harga Saham perusahaan .

9. Secara bersamaan terdapat pengaruh NPL, LDR, GCG, NIM, ROA, ROE, CAR, BOPO terhadap Harga Saham perusahaan.

\section{METODOLOGI}

\section{Lokasi dan Waktu Penelitian}

Penelitian dilakukan di Bursa Efek Indonesia dari tahun 2010 hingga 2014. Melalui web site resmi Bursa Efek Indonesia www.idx.co.id, www.bi.go.id, www.bloomberg.com, dan web site perbankan terkait. Sedangkan waktu penelitian akan dilaksanakan $\underline{8}$ bulan yaitu AprilNopember 2016. 


\section{Jenis Penelitian}

Penelitian ini merupakan penelitian yang menggunakan pendekatan kuantitatif dimana data bersumber dari laporan keuangan yang dibuplikasikan oleh perusahaan - perusahaan yang menjadi sampel dalam penelitian ini. Untuk mengolah dan menganalisis data-data yang terkumpul dilakukan dengan distribusi frekuensi, korelasi product moment, korelasi ganda, regresi linier sederhana dan regresi ganda. Pada penelitian ini dilakukan penelitian korelasi kuatnya hubungan antara variable bebas dengan variable terikat dengan metode analisis korelasi dan melakukan prediksi persamaan garis yang sesuai dengan analisis regresi linier (Sugiyono, 2004 ; 170) Untuk ketepatan penghitungan sekaligus mengurangi Human error digunakanlah program SPSS 21.

\section{Variabel Penelitian}

Varibel penelitian ini terdiri dari dua jenis variable, variable bebas (independentvariable), dan variable terikat (dependent variable). Penelitian ini terdiri 9 variabel yaitu 8 variable bebas dan 1 variable terikat. Variabel bebas yang pertama adalah NPL yang selanjutnya disebut X1, variable yang kedua LDR adalah yang selanjutnya disebut X2, GCG (X3), NIM (X4), ROA (X5), ROE (X6), CAR (X7), BOPO (X8) sedangkan variable terikat adalah Harga Saham perusahaan yang selanjutnya disebut dengan $\mathrm{Y}$.

\section{Populasi dan Sampel Penelitian}

Dalam Penelitian ini yang menjadi populasi adalah Perusahaan perbankkan yangterdaftar di Bursa Efek Indonesia. Pengambilan sampel dilakukan dengan metode "purposive sampling". Yang merupakan teknik penentuan sampel dengan pertimbangantertentu. Sampel yang digunakan adalah sampel yang memenuhi kriteria sebagai berikut:

1. Bank telah terdaftar di BEI sejak tahun 2010 atau sebelumnya.

2. Bank yang masih eksis atau beroperasi pada periode waktu 2010-2014 (tidak dibekukan atau dilikuidasi oleh pemerintah).

3. Tersedia Laporan Keuanga yang diaudit dan dipublikasikan Serta mempunyai data secara lengkap (rasio yang digunakan seperti Variabel diatas). 
4. Bank tersebut tidak pernah mengalami kerugian dari tahun 2010 -2014

Terdapat 41 Perusahaan Perbankan yang terdaftar di Bursa Efek Indonesia tahun 2014, tetapi yang memenuhi kriteria sebagai sampel hanya terdapat 20 perusahaan perbankan, sedangkan angka tahun yang digunakan adalah 5 tahun berturut - turut, sehingga jumlah sampel adalah 5 x $20=100$ sampel. Adapun Nama perusahaan yang memenuhi kriteria yaitu seperti table dibawah:

Tabel 1 Nama Sampel Perusahaan Perbankan

\begin{tabular}{|c|c|c|c|}
\hline No & $\begin{array}{c}\text { Kode } \\
\text { Saham }\end{array}$ & Nama Emiten & Tanggal IPO \\
\hline 1 & BAEK & Bank Ekonomi Raharja Tbk & 8-Jan-08 \\
\hline 2 & BBCA & Bank Central Asia Tbk & 31-May-00 \\
\hline 3 & BBKP & Bank Bukopin Tbk & 10-Jul-06 \\
\hline 4 & BBNI & Bank Negara Indonesia (Persero)Tbk & 25-Nov-96 \\
\hline 5 & BBNP & Bank Nusantara Parahyangan Tbk & 10-Jan-01 \\
\hline 6 & BBRI & Bank Rakyat Indonesia (Persero)Tbk & 10-Nov-03 \\
\hline 7 & BDMN & Bank Danamon Indonesia Tbk & 6-Dec-89 \\
\hline 8 & BMRI & Bank Mandiri (Persero) Tbk & 14-Jul-03 \\
\hline 9 & BNBA & Bank Bumi Arta Tbk & 31-Dec-99 \\
\hline 10 & BNGA & $\begin{array}{l}\text { Bank CIMB Niaga Tbk } \\
\text { d.h. Bank Niaga Tbk }\end{array}$ & 29-Nov-89 \\
\hline 11 & BNII & $\begin{array}{lc}\text { Bank Internasional Indonesia Tbk } & \text { d.h. } \\
\text { BII Maybank Tbk } & \text { d.h. } \\
\text { Bank Internasional Indonesia Tbk } & \end{array}$ & 21-Nov-89 \\
\hline 12 & BNLI & $\begin{array}{l}\text { Bank Permata Tbk } \\
\text { d.h. Bank Bali }\end{array}$ & 15-Jan-90 \\
\hline 13 & BSWD & $\begin{array}{l}\text { Bank of India Indonesia Tbk } \\
\text { d.h. Bank Swadesi Tbk }\end{array}$ & 1-May-02 \\
\hline 14 & BTPN & Bank Tabungan Pensiunan Nasional Tbk & 12-Mar-08 \\
\hline 15 & INPC & $\begin{array}{r}\text { Bank Artha Graha International Tbk } \\
\text { Bank Interpacific Tbk }\end{array}$ & 29-Aug-90 \\
\hline 16 & MCOR & $\begin{array}{c}\text { Bank Windu Kentjana International Tbk d.h. Bank } \\
\text { Multicor International Tbk }\end{array}$ & 3-Jul-07 \\
\hline 17 & MEGA & Bank Mega Tbk & 17-Apr-00 \\
\hline 18 & NISP & $\begin{array}{l}\text { Bank OCBC NISP Tbk } \\
\text { d.h. Bank NISP Tbk }\end{array}$ & 20-Oct-94 \\
\hline 19 & PNBN & Bank Pan Indonesia Tbk & 29-Dec-82 \\
\hline 20 & SDRA & $\begin{array}{l}\text { Bank Himpunan Saudara } 1906 \text { Tbk } \\
\text { d.h.Bank Himpunan Saudara } 1906 \text { Tbk }\end{array}$ & 15-Dec-06 \\
\hline
\end{tabular}

Sumber : Data diolah 2016 


\section{Teknik Analisis Data}

Teknik analisis data yang digunakan untuk memecahkan permasalahan dalam penelitian ini adalah menggunakan analisis regresi linier berganda. Analisis ini dipergunakan untuk mengetahui dan memperoleh gambaran mengenai hubungan NPL (NonPerforming Loan), LDR (Loan to Deposit Ratio), GCG (Good Corporate Governance),NIM (Net Interest Margin), ROA (Return on Assets), ROE (Return on Equity), CAR (Capital Adequacy Ratio), BOPO (Beban Operasional terhadap PendapatanOperasional) terhadap Harga Saham.Dengan menggunakan program SPSS(Statistical Product and Service Solutions).

\section{PEMBAHASAN}

\section{Hasil Penelitian}

\section{Statistik Deskriptif}

Berdasarkan hasil pengolahan data pada lampiran memberikan gambaran awal terhadap pola penyebaran variabel penelitian. Gambaran ini sangat berguna untuk memenuhi kondisi dari populasi penelitian yang bermanfaan dalam pembahasan dan penganalisis model. Pada bagian ini akan dideskripsikan data masing-masing variabel dari 120 sampel dengan menghitung rata rata, nilai minimum, nilai maksimum, range dan standar deviasi. Adapun deskripsi data adalah:

\section{Tabel 2. Statistik Deskriptif}

\section{Descriptive Statistics}

\begin{tabular}{ccccccccc}
\hline & $\mathrm{N}$ & Range & Min & Max & Sum & Mean & Std. Deviation & Variance \\
\hline NPL & 100 & 4.15 & .21 & 4.36 & 172.34 & 1.7234 & .92764 & .861 \\
LDR & 100 & 48.81 & 52.39 & 101.20 & 8248.29 & 82.4829 & 10.47811 & 109.791 \\
GCG & 100 & 3 & 2 & 5 & 431 & 4.31 & .662 & .438 \\
NIM & 100 & 10.02 & 3.38 & 13.40 & 609.38 & 6.0938 & 2.29548 & 5.269 \\
ROA & 100 & 4.49 & .66 & 5.15 & 229.54 & 2.2954 & 1.17121 & 1.372 \\
ROE & 100 & 37.55 & 5.28 & 42.83 & 1774.41 & 17.7441 & 9.06352 & 82.147 \\
CAR & 100 & 15.24 & 11.67 & 26.91 & 1640.66 & 16.4066 & 3.05776 & 9.350 \\
BOPO & 100 & 45.26 & 54.00 & 99.26 & 7833.77 & 78.3377 & 10.35878 & 107.304 \\
HS & 100 & 11871 & 79 & 11950 & 268128 & 2681.28 & 2938.453 & 8634506.527 \\
Valid N & 100 & & & & & & & \\
(listwise) & & & & & & & & \\
\hline
\end{tabular}

Sumber : Data yang diolah, 2016

\section{Uji Asumsi Klasik}


Untuk menghasilkan suatu model regresi yang baik, Sebelum dilakukan pengujian hipotesis maka harus kita lakukan terlebih dahulu pengujian asumsi klasik yang meliputi pengujian normalitas, linieritas, multikolinearitas, autokorelasi dan heteroskedastisitas. Karena ini adalah dasar model regresi linier berganda

\section{Uji Normalitas}

Uji normalitas ini dilakukan dengan tujuan untuk menguji apakah dalam sebuah model regresi variabel dependen dan variabel independen mempunyai distribusi normal atau tidak. Model regresi yang baik dan layak digunakan dalam penelitian adalah distribusi data normal atau mendekati normal.

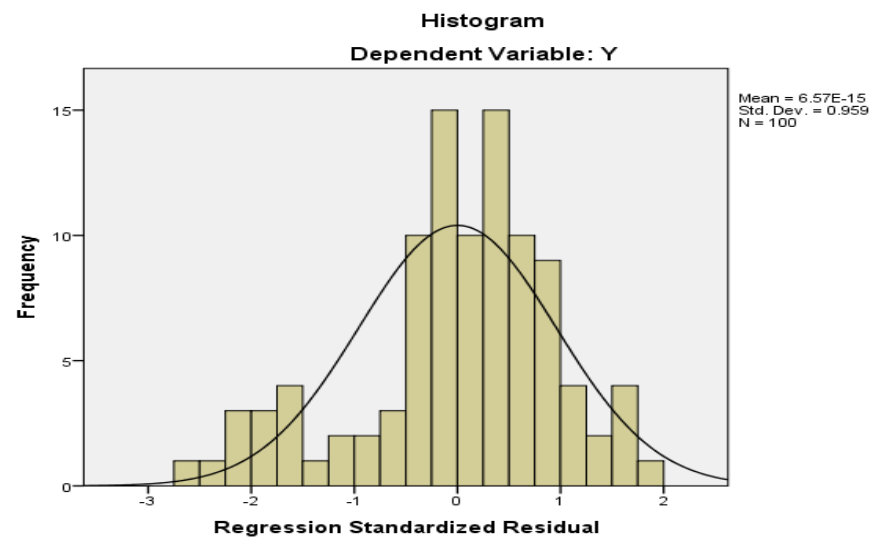

Dari Gambar diatas menunjukkan kurva dengan kemiringan yang cenderung seimbang baik pada sisi kanan maupun pada sisi kiri, dan kurva berbentuk menyerupai lonceng yang hampir sempurna. Dari hasil tampilan grafik histogram variable X1, X2, X3, X4, X5, X6, X7, X8 dan Y menunjukkan normal.

\section{Uji Normalitas}

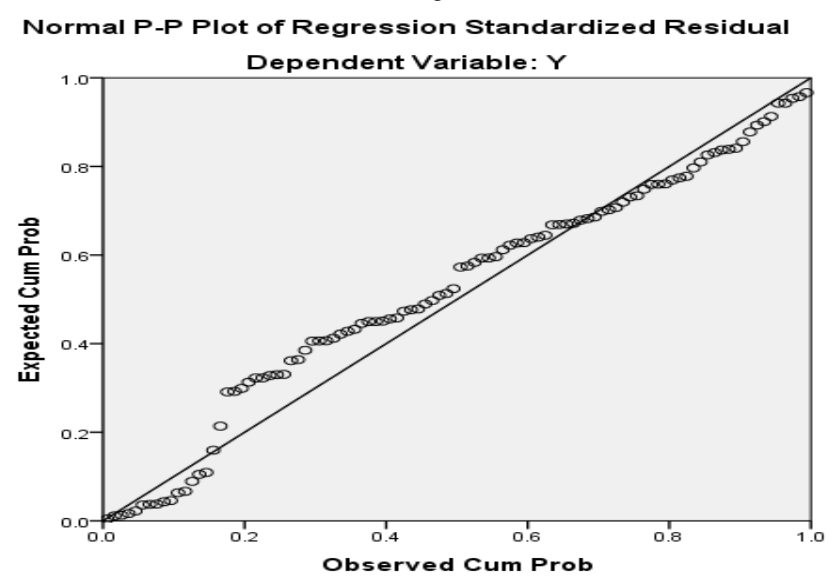




\section{Uji Multikolinieritas}

\begin{tabular}{cccc}
\multirow{2}{*}{ Coefficients $^{\mathrm{a}}$} & \multicolumn{3}{c}{ Tabel. 3 Uji Multikolinieritas } \\
\cline { 2 - 4 } Model & \multicolumn{3}{c}{ Collinearity Statistics } \\
\cline { 2 - 4 } (Constant) & & Tolerance & \\
X1 & .915 & 1.093 \\
X2 & .705 & 1.419 \\
& X3 & .832 & 1.202 \\
1 & X4 & .544 & 1.839 \\
& X5 & .787 & 1.508 \\
X6 & .157 & 6.383 \\
& X7 & .560 & 1.786 \\
X8 & .275 & 3.634 \\
\hline
\end{tabular}

a. Dependent Variable: Y

Pengujian multikolinieritas digunakan untuk menguji apakah model regresi ditemukan adanya korelasi yang kuat antar variabel independen. Model regresi yang baik seharusnya tidak terjadi kolinearitas diantara variabel bebas. Nilai umum yang dipakai untuk menunjukkan tidak adanya multikolinearitas adalah nilai $\mathrm{VIF}<10$ dan nilai Tolerance $>0,10$.

Dari hasil pengujian bahwa variabel independen memiliki nilai VIF dalam batas toleransi yang ditentukan sehingga tidak terjadi multikolinieritas dalam variabel independen penelitian ini.

\section{Uji Heteroskedastisitas}

Model regresi yang baik adalah yang homoskodesitas atau tidak terjadi heterokedastisitas.Uji ini dilakukan dengan menggunakan analisis grafik scatterplot antara nilai prediksi variabel terikat ZPRED dengan residualnya SPRESID. Dari grafik scatterplot terlihat bahwa titik-titik menyebar secara acak di atas maupun di bawah angka 0 pada sumbu Y. Hal ini dapat disimpulkan bahwa tidak terjadi heteroskedastisitas pada model regresi. 


\section{Grafik 2.2 Uji Heterokedastisitas}

Scatterplot

Dependent Variable: $Y$

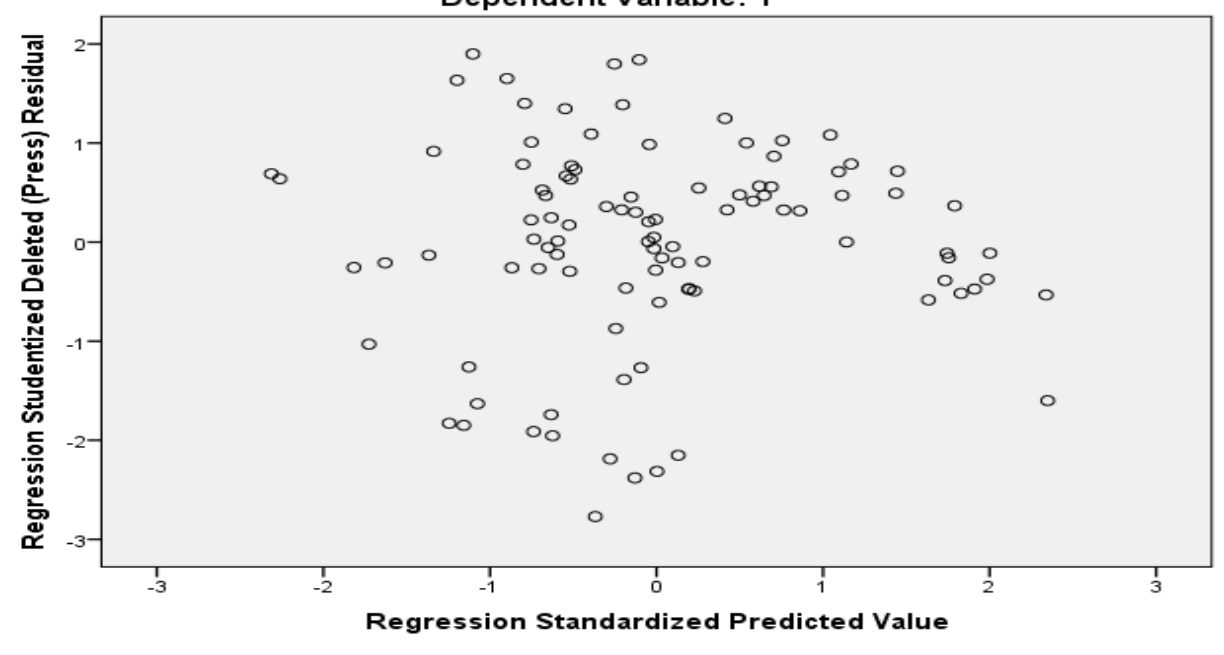

\section{Uji Autokorelasi}

Uji autokorelasi digunakan untuk mengetahui dan mendeteksi adanya autokorelasi. Autokorelasi dalam penelitian dengan menggunakan besaran Durbin Watson. Model regresi yang baik adalah model regresi yang bebas dari autokorelasi. Hasil uji autokorelasi :

Tabel.4 Uji Autokorelasi Model Summary ${ }^{\text {b }}$

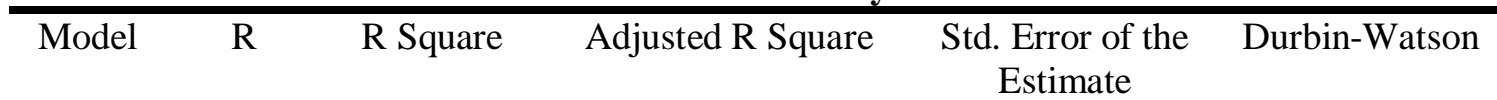

\begin{tabular}{llllll}
\hline 1 & $.798^{\mathrm{a}}$ & .637 & .606 & .36470 & 1.715 \\
\hline
\end{tabular}

a. Predictors: (Constant), X8, X2, X1, X3, X7, X4, X6, X5

b. Dependent Variable: Y

Untuk menguji ada tidaknya autokorelasi, Maka dideteksi dengan uji Durbin - Watson (DW). Bila Du < Dw < 4-Du maka coefisien autokorelasi sama dengan nol, yang berarti tidak ada autokorelasi. Dari nilai di bawah terlihat bahwa Durbin Watson (DW) adalah 1.715. dL = 1,6543 dan $\mathrm{dU}=1,7715$ dengan demikian dapat disimpulkan tidak terjadi autokorelasi di dalam penelitian ini.

\section{Hasil Analisis Data}


Dari hasil pengujian asumsi klasik disimpulkan bahwa model regresi yang dipakai dalam penelitian ini telah memenuhi model estimasi yang Best Linier Unbiased Estimator (BLUE) dan layak dilakukan analisis regresi.

\section{Persamaan Regresi}

Dalam pengolahan data dengan menggunakan regresi linier, dilakukan beberapa tahapan untuk mencari hubungan antara variable independen dan variable dependen. Hasil persamaan regresi linier dalam penelitian ini dapat dilihat pada Tabel berikut:

\section{Tabel.5 Analisis Regresi}

\begin{tabular}{|c|c|c|c|c|c|}
\hline \multicolumn{6}{|c|}{ Coefficients $^{\mathrm{a}}$} \\
\hline \multirow[t]{2}{*}{ Model } & \multicolumn{2}{|c|}{ Unstandardized Coefficients } & \multirow{2}{*}{$\frac{\text { Standardized Coefficients }}{\text { Beta }}$} & \multirow[t]{2}{*}{$\mathbf{t}$} & \multirow[t]{2}{*}{ Sig. } \\
\hline & B & Std. Error & & & \\
\hline (Constant) & 4.463 & .900 & & 2.736 & .007 \\
\hline $\mathrm{X} 1$ & .197 & .046 & .138 & 2.098 & .039 \\
\hline $\mathrm{X} 2$ & .209 & .004 & .007 & 1.097 & .923 \\
\hline X3 & .205 & .528 & .289 & 4.177 & .000 \\
\hline $\mathrm{X} 4$ & .944 & .380 & .235 & 2.751 & .007 \\
\hline X5 & .172 & .107 & .144 & 1.672 & .504 \\
\hline X6 & .120 & .010 & .311 & 1.951 & .054 \\
\hline$X 7$ & .101 & .019 & .002 & 2.027 & .979 \\
\hline X8 & .120 & .007 & .352 & 2.923 & .004 \\
\hline
\end{tabular}

a. Dependent Variable: Y

Dari table diatas maka model regresi berganda antara variabel $\mathrm{X}$ terhadap $\mathrm{Y}$ dapat diformulasikan dalam model persamaan sebagai berikut :

$\mathrm{Y}=a+b 1 \times 1+b 2 \times 2+b 3 \times 3+b 4 \times 4+b 5 \times 5+b 6 \times 6+b 7 \times 7+b 8 \times 8+e$

$\mathrm{Y}=4.463+0.197 \mathrm{NPL}+0.209 \mathrm{LDR}+0.205 \mathrm{GCG}+0.944 \mathrm{NIM}+0.172 \mathrm{ROA}+0.120 \mathrm{ROE}+$ 0.101CAR + 0.120BOPO + e

Dari hasil persamaan regresi berganda tersebut, masing-masing variabel bebas dapat diinterpretasikan pengaruhnya terhadap harga saham sebagai berikut :

1. $\alpha=4.463$. Nilai konstanta ini menunjukkan bahwa apabila tidak ada variabel $\mathrm{X} 1, \mathrm{X} 2$, X3, X4, X5, X6, X7, dan X8 maka Y adalah sebesar 4.463

2. $\mathrm{b} 1=0.197$ Koefisien regresi b1 menunjukkan bahwa setiap variabel $\mathrm{X} 1$ meningkat sebesar satu persen, maka Y akan bertambah sebesar 0.197 atau 19.7\%. Dengan asumsi variabel independen lainnya dianggap tetap atau sama dengan nol.

3. $\mathrm{b} 2=0.209$ Koefisien regresi b2 menunjukkan bahwa setiap variabel X2 meningkat sebesar satu persen, maka Y akan bertambah sebesar 0.209 atau 20.9\%. Dengan asumsi variabel independen lainnya dianggap tetap atau sama dengan nol. 
4. $\mathrm{b} 3=0.205 \mathrm{Koefisien}$ regresi b3 menunjukkan bahwa setiap variabel $\mathrm{X} 3$ meningkat sebesar satu persen, maka Y akan bertambah sebesar 0.205 atau 20.5\%. Dengan asumsi variabel independen lainnya dianggap tetap atau sama dengan nol.

5. b4 $=0.944$ Koefisien regresi b4 menunjukkan bahwa setiap variabel $\mathrm{X} 4$ meningkat sebesar satu persen, maka Y akan bertambah sebesar 0.944 atau 94,4\%. Dengan asumsi variabel independen lainnya dianggap tetap atau sama dengan nol.

6. b $5=0.172$ Koefisien regresi b5 menunjukkan bahwa setiap variabel X5 meningkat sebesar satu persen, maka Y akan bertambah sebesar 0.172 atau $17.2 \%$. Dengan asumsi variabel independen lainnya dianggap tetap atau sama dengan nol.

7. b $6=0.120$ Koefisien regresi b6 menunjukkan bahwa setiap variabel X6 meningkat sebesar satu persen, maka Y akan bertambah sebesar 0.120 atau $12 \%$. Dengan asumsi variabel independen lainnya dianggap tetap atau sama dengan nol.

8. b $7=0.101$ Koefisien regresi b7 menunjukkan bahwa setiap variabel $\mathrm{X} 7$ meningkat sebesar satu persen, maka Y akan bertambah sebesar 0.101 atau 10,1\%. Dengan asumsi variabel independen lainnya dianggap tetap atau sama dengan nol.

9. b $8=0.120$ Koefisien regresi b8 menunjukkan bahwa setiap variabel $\mathrm{X} 8$ meningkat sebesar satu persen, maka Y akan bertambah sebesar 0.120 atau $12 \%$. Dengan asumsi variabel independen lainnya dianggap tetap atau sama dengan nol.

\section{Pengujian Hipotesis}

Pengujian hipotesis dilakukan untuk mengetahui apakah variabel independen berpengaruh terhadap variabel dependen baik secara simultan maupun parsial. Ada tiga cara untuk pengujian hipotesis yaitu uji f, uji t, dan r2.

\section{Uji Statistik F}

Uji statistik F dilakukan untuk mengetahui apakah variabel independen yang dimasukkan dalam model mempunyai pengaruh secara bersama-sama terhadap variabel dependen. Uji statistik F disajikan pada Tabel dibawah:

Tabel 6. Uji Statistik F

\begin{tabular}{|c|c|c|c|c|c|c|}
\hline \multicolumn{7}{|c|}{ ANOVA $^{a}$} \\
\hline Model & & $\begin{array}{l}\text { Sum of } \\
\text { Squares }\end{array}$ & $\mathrm{df}$ & Mean Square & $\mathrm{F}$ & Sig. \\
\hline \multirow{3}{*}{1} & Regression & 21.281 & 8 & 2.660 & 20.000 & $.000^{\mathrm{b}}$ \\
\hline & Residual & 12.104 & 91 & .133 & & \\
\hline & Total & 33.385 & 99 & & & \\
\hline
\end{tabular}

a. Dependent Variable: Y

b. Predictors: (Constant), X8, X2, X1, X3, X7, X4, X6, X5

Berdasarkan hasil uji statistik F pada Tabel 5.7. menunjukkan bahwa nilai Fhitung adalah 20.000 dengan tingkat signifikansi 0,000. Sedangkan Ftabel pada tingkat kepercayaan $95 \%(\alpha=$ 
DIMENSI, VOL. 6, NO. 1: 22-40

JANUARI 2017

ISSN: 2085-9996

0,05) adalah 2.60. Oleh karena pada kedua perhitungan Fhitung > Ftabel (20.000>2.60). Hal ini menunjukkan bahwa variabel independen NPL, LDR, GCG, NIM, ROA, ROE, CAR dan BOPO secara simultan berpengaruh terhadap variabel dependen harga saham perusahaan perbankan yang terdaftar di BEI periode 2010-2014.

\section{Uji Statistik t}

Uji statistik t pada dasarnya menunjukkan seberapa jauh pengaruh satu variabel independen secara individual dalam menerangkan variasi variabel terikat. Apabila nilai thitung lebih besar daripada nilai ttabel dapat disimpulkan bahwa suatu variabel independen secara individual mempengaruhi variabel dependen. Untuk melihat $t$ hitung lihat table di bawah:

Tabel. 7 Uji t Hitung

Coefficients $^{\mathbf{a}}$

\begin{tabular}{|c|c|c|c|c|c|c|}
\hline \multirow[t]{2}{*}{ Model } & & \multicolumn{2}{|c|}{ Unstandardized Coefficients } & \multirow{2}{*}{$\begin{array}{c}\text { Standardized } \\
\text { Coefficients } \\
\text { Beta }\end{array}$} & \multirow[t]{2}{*}{$\mathrm{t}$} & \multirow[t]{2}{*}{ Sig. } \\
\hline & & B & Std. Error & & & \\
\hline \multirow{9}{*}{1} & (Constant) & 2.463 & .900 & & 2.736 & .007 \\
\hline & $\mathrm{X} 1$ & -.097 & .046 & -.138 & 2.098 & .039 \\
\hline & $\mathrm{X} 2$ & .000 & .004 & -.007 & -.097 & .923 \\
\hline & $\mathrm{X} 3$ & 2.205 & .528 & .289 & 4.177 & .000 \\
\hline & $\mathrm{X} 4$ & 1.044 & .380 & .235 & 2.751 & .007 \\
\hline & X5 & -.072 & .107 & -.144 & -.672 & .504 \\
\hline & X6 & .020 & .010 & .311 & 1.951 & .054 \\
\hline & $\mathrm{X} 7$ & .001 & .019 & .002 & .027 & .979 \\
\hline & X8 & -.020 & .007 & -.352 & 2.923 & .004 \\
\hline
\end{tabular}

a. Dependent Variable: Y

Hasil uji t Hitung terhadap Harga Saham sesuai dengan table diatas adalah:

1. Non Performing Loan (X1) Terhadap Harga Saham (Y). Berdasarkan hasil perhitungan dengan SPSS table di atas tampak nilai $t_{\text {hitung }}>\mathrm{t}_{\text {tabel }}$ yaitu $2.098>1955$ dan nilai signifikan lebih kecil dari pada tingkat $\alpha$ yang digunakan yaitu 0.05 atau $0.039<0.05$, sehingga dapat disimpulkan bahwa H0 ditolak. Yang artinya terdapat pengaruhpositifdan signifikan antara Non Performing Loan (X1) Terhadap Harga Saham (Y).

2. Loan to Deposit Ratio (X2)Terhadap Harga Saham (Y)Berdasarkan hasil perhitungan dengan SPSS table di atas tampak nilai $t_{\text {hitung }}<\mathrm{t}_{\text {tabel }}$ yaitu $0.097<1955$ dan nilai signifikan lebih 
kecil dari pada tingkat $\alpha$ yang digunakan yaitu 0.05 atau $0.923>0.05$, sehingga dapat disimpulkan bahwa $\mathrm{H} 0$ diterima. Yang artinya tidak terdapat pengaruh yang signifikan antara Loan to Deposit Ratio (X2)Terhadap Harga Saham (Y).

3. Good Corporate Governance (X3) Terhadap Harga Saham (Y). Berdasarkan hasil perhitungan dengan SPSS table di atas tampak nilai $t_{\text {hitung }}>t_{\text {tabel }}$ yaitu $4.177>1955$ dan nilai signifikan lebih kecil dari pada tingkat $\alpha$ yang digunakan yaitu 0.05 atau $0.000<0.05$, sehingga dapat disimpulkan bahwa $\mathrm{H} 0$ ditolak. Yang artinya terdapat pengaruh positif dan signifikan antara Good Corporate Governance (X3)Terhadap Harga Saham (Y).

4. Net Interest Margin (X4) Terhadap Harga Saham (Y). Berdasarkan hasil perhitungan dengan SPSS table di atas tampak nilai $t_{\text {hitung }}>t_{\text {tabel }}$ yaitu $2.751>1955$ dan nilai signifikan lebih kecil dari pada tingkat $\alpha$ yang digunakan yaitu 0.05 atau $0.007<0.05$, sehingga dapat disimpulkan bahwa H0 ditolak. Yang artinya terdapat pengaruh positif dan signifikan antara Net Interest Margin (X4)Terhadap Harga Saham (Y).

5. Return on Assets (X5)Terhadap Harga Saham (Y). Berdasarkan hasil perhitungan dengan SPSS table di atas tampak nilai $\mathrm{t}_{\text {hitung }}<\mathrm{t}_{\text {tabel }}$ yaitu $0.672<1955$ dan nilai signifikan lebih kecil dari pada tingkat $\alpha$ yang digunakan yaitu 0.05 atau $0.504>0.05$, sehingga dapat disimpulkan bahwa $\mathrm{H} 0$ diterima. Yang artinya tidak terdapat pengaruh yang signifikan antara Return on Assets (X5)Terhadap Harga Saham (Y).

6. Return on Equity (X6) Terhadap Harga Saham (Y). Berdasarkan hasil perhitungan dengan SPSS table di atas tampak nilai $\mathrm{t}_{\text {hitung }}<\mathrm{t}_{\text {tabel }}$ yaitu $1.951<1955$ dan nilai signifikan lebih kecil dari pada tingkat $\alpha$ yang digunakan yaitu 0.05 atau $0.054>0.05$, sehingga dapat disimpulkan bahwa $\mathrm{HO}$ diterima. Yang artinya tidak terdapat pengaruh yang signifikan antara Return on Equity (X6) Terhadap Harga Saham (Y).

7. Capital Adequacy Ratio (X8) Terhadap Harga Saham (Y). Berdasarkan hasil perhitungan dengan SPSS table di atas tampak nilai thitung $>t_{\text {tabel }}$ yaitu $2.923>1955$ dan nilai signifikan lebih kecil dari pada tingkat $\alpha$ yang digunakan yaitu 0.05 atau $0.004<0.05$, sehingga dapat disimpulkan bahwa $\mathrm{H} 0$ ditolak. Yang artinya terdapat pengaruh positif dan signifikan antara Capital Adequacy Ratio (X8)Terhadap Harga Saham (Y).

8. Beban Operasional / Pendapatan Operasional (X7) Terhadap Harga Saham (Y). Berdasarkan hasil perhitungan dengan SPSS table di atas tampak nilai $\mathrm{t}_{\text {hitung }}<\mathrm{t}_{\text {tabel }}$ yaitu $0.027<1955$ dan nilai signifikan lebih kecil dari pada tingkat $\alpha$ yang digunakan yaitu 0.05 atau $0.979>0.05$, 
sehingga dapat disimpulkan bahwa H0 diterima. Yang artinya tidak terdapat pengaruh yang signifikan antara Beban Operasional / Pendapatan Operasional (X7) Terhadap Harga Saham (Y).

\section{Koefisien determinasi (R2)}

Hasil uji hipotesis yang menyatakan bahwa ROA, ROE dan PER mempunyai pengaruh terhadap harga saham, untuk meyakinkan atau tingkat kekuatan hubungan antar variabel dapat dilihat pada tabel koefisien determinasi berikut ini :

Tabel 8. Koefisien Determinasi (R2)

Model Summary ${ }^{\text {b }}$

\begin{tabular}{l|r|r|r}
\hline Model & \multicolumn{1}{|c|}{ R } & \multicolumn{1}{|c}{ R Square } & \multicolumn{1}{|c}{ Adjusted R Square } \\
\hline 1 & $.798^{\mathrm{a}}$ & .637 & .606 \\
\hline
\end{tabular}

a. Predictors: (Constant), X8, X2, X1, X3, X7, X4, X6, X5

b. Dependent Variable: Y

Untuk memerikasa apakah model persamaan regresi linear yang terestimasi sudah cukup baik atau tidak. Atau dengan kata lain nilai R-square adalah untuk melihat bagaimana variasi nilai variable terikat dipengaruhi oleh variasi nilai variable bebas. Terlihat di bawah bahwa RSquare adalah 0,637 yang artinya harga saham ditentukan oleh variable variable tersebut adalah $63,7 \%$ sedangkan 36,3\% lagi ditentukan oleh variable lain. Dan terlihat bahwa adjusted R square adalah 0.606 yang artinya 60,6\% berpengaruh terhadap harga saham sedangkan 39,4\% ditentukan oleh variable lainnya yang tidak dijelaskan oleh model penelitian ini terangkum dalam error.

\section{KESIMPULAN DAN SARAN}

\section{Kesimpulan}

Dari hasil analisis data penelitian yang telah dilakukan dapat disimpulkan bahwa :

1. Secara parsial Terdapat pengaruh signifikan antara NPL terhadap harga saham pada perusahaan perbankan di BEI.

2. Secara parsial Terdapat pengaruh tidak signifikan antara LDR terhadap harga saham pada perusahaan perbankan di BEI. 
3. Secara parsial Terdapat pengaruh signifikan antara GCG terhadap harga saham pada perusahaan perbankan di BEI.

4. Secara parsial Terdapat pengaruh signifikan antara NIM terhadap harga saham pada perusahaan perbankan di BEI.

5. Secara parsial Terdapat pengaruh tidak signifikan antara ROA terhadap harga saham pada perusahaan perbankan di BEI.

6. Secara parsial Terdapat pengaruh tidak signifikan antara ROE terhadap harga saham pada perusahaan perbankan di BEI.

7. Secara parsial Terdapat pengaruh tidak signifikan antara CAR terhadap harga saham pada perusahaan perbankan di BEI.

8. Secara parsial Terdapat pengaruh signifikan antara BOPO terhadap harga saham pada perusahaan perbankan di BEI.

9. Secara simultan variabel-variabel independen NPL, LDR, GCG, NIM, ROA, ROE, CAR dan BOPO berpengaruh signifikan terhadap harga saham perusahaan Perbankan yang terdaftar di BEI.

\section{Saran}

Adapun saran dalam penelitian ini adalah :

1. Adanya keterbatasan dari tingkat penilaian GCG yang dilakukan secara Self Asessment oleh bank yang diteliti. Walaupun Penilaiannya telah ditetapkan menurut SE No. 15/15/DPNP Bank Indonesia yang paling kurang harus diwujudkan dalam 11 aspek penilaia dan telah sesuai dengan tahapan penilaian Corporate Govermance Perception Index (CGPI) tetapi penilaian bank ini masih dilakukan sendiri.

\section{REFERENSI}

Anthony, Robert N. dan Vijay Govindarajan. 2005. Management Control System. Salemba Empat : Jakarta.

Bank Indonesia. 2010. Laporan Keuangan Tahunan. www.bi.go.id

Bank Indonesia. 2011. Laporan Keuangan Tahunan. www.bi.go.id

Bank Indonesia. 2012. Laporan Keuangan Tahunan. www.bi.go.id 
Bank Indonesia. 2013. Laporan Keuangan Tahunan. www.bi.go.id

Bank Indonesia. 2014. Laporan Keuangan Tahunan. www.bi.go.id

Budisantoso Totok, triandaru Sigit. 2006. Bank dan Lembaga Keuangan Lain. Jakarta : salemba Empat.

Brigham and Houston. 2006. Dasar-dasar Manajemen Keuangan. Edisi Kesepuluh. Jakarta : Salemba Empat.

Chariri, anis dan Ghozali. 2007. Teori Akuntansi. Fakultas Ekonomi : Universitas Diponegoro Semarang.

Fahmi, Irham 2011. Analisis Laporan Keuangan. Bandung: Penerbit Alfabeta.

Gitosudarmo, Indriyo dan Basri. 2008. Manajemen Keuangan. Edisi Keempat. Yogyakarta: $\mathrm{BFE}$

Gujarati, Damodar. N. (2007). Dasar-dasar Ekonometrika. Edisi Ketiga. Jakarta : Erlangga.

Ghozali, Imam. 2006. Analisis Multivariate Dengan Program SPSS. Edisi ke 4. Badan Penerbit Universitas Diponegoro : Semarang.

Hanafi dan Halim. 2009. Analisis Laporan Keuangan. Edisi keempat. Jakarta: Sekolah Tinggi Ilmu Manajemen YKPN.

Lubis, Ade Fatma. 2008. Pasar Modal. Jakarta : Lembaga Penerbit Fakultas Ekonomi UI. 